\title{
Development of Interactive E-books on Plane Figures Materials to Improve Problem Solving Ability of Grade IV Students
}

\author{
Rahma Setiyanigrum $^{1}$, Endang Susilaningsih ${ }^{2}$, Nas Haryati Setyaningsih ${ }^{3}$ \\ ${ }^{1,2,3}$ Basic Education Study Program, Postgraduate Faculty, Semarang State University, Semarang, Indonesia \\ Corresponding Author: Rahma Setiyanigrum
}

DOI: https://doi.org/10.52403/ijrr.20220240

\begin{abstract}
The purpose of this study was to analyze content validity, practicality, readability, effectiveness, and student responses using an interactive ebook of plane figures materials designed to improve the problem-solving abilities of fourth grade students. This research is Research and Development (R\&D) with ADDIE design which includes five stages: analysis, design, development, implementation, and evaluation. The interactive e-book was validated by two validators, namely material experts and media experts. The small scale trial involved six fifth grade students of SD 1 Pasuruhan Lor, the large scale trial involved 38 fourth grade students of SD 1 and SD 2 Pasuruan Lor. Interviews, questionnaires, and tests were all used to collect data. The results showed that the content validity was $86.67 \%$ with very good criteria for material expert validators and $96.49 \%$ with very valid criteria for media expert validators. Readability is $63.13 \%$ with easy to understand criteria. Practicality is $89.41 \%$ with very practical criteria according to the results of teacher practicality questionnaires, and $93.29 \%$ with very practical criteria according to student practicality questionnaires. The effectiveness is determined by the classical completeness score of $76.32 \%>75 \%$ and the $\mathrm{N}$-gain value of 1.49 with very high criteria. Students' responses to interactive e-books are $92.42 \%$ with very good criteria. Based on the results of the research, it can be stated that the development of an interactive e-book of plane figures materials to improve the problem-solving abilities $s$ of fourth grade students is valid, readable, practical,
\end{abstract}

effective, and gets a good response from students.

Keywords: Interactive e-book, Circumference and Area, Problem Solving Skills

\section{INTRODUCTION}

One of the lessons in elementary school is learning mathematics. Johnson \& Rising in (Isrok'atun \& Rosmala, 2018:3) stated mathematics is a language that is precisely defined, clear, and accurately portrayed through the use of symbols. Mathematics education in elementary schools is closely associated to activities centered on problem solving, particularly difficulties encountered by students on a daily basis. Laurens et al., (2018: 569) asserts that mathematics is a subject that must be learned by students and is the basic capital, especially in problem solving activities in daily life Kemendikbud (2017) mentioned that the purpose of learning mathematics in elementary school is to develop problem-solving abilities.

According to the findings of interviews conducted in Pasuruhan Lor grades IV SD 1 and 2, it is known that students' ability to address problems is still low. Zuliana (2015:2) explained that the conditions that contribute to low problemsolving abilities are that students are unfamiliar with the nature of the problem and the strategies for resolving it. Loc \& Phuong (2015:14564) Additionally, children 
have trouble developing problem-solving strategies and frequently make mistakes during the problem-solving process. Apart from the students' poor problem-solving abilities, it is well-known that the material for circumference and area of plane figures is tough for students. Fauzi \& Arisetyawan (2020:29) stated that the circumference and area of a flat object are calculated using methods that are difficult for children to comprehend. Students are still in the concrete operational level, which requires instruction in complex geometric material that include formal symbols and operations. This makes it difficult for kids to comprehend the diameter and area of a flat figure.

Additionally, the results of the interviews indicate that current learning resources, such as teaching materials used by teachers, are limited to governmentissued textbooks as well as textbooks from other publishers, and that current learning resources do not adequately address students' needs for learning activities. Teachers' limited time and workload are additional impediments to developing more engaging and interactive instructional materials. Teaching materials have developed in lockstep with technological developments. The rapid development of smartphones and computers, the width of the internet network, and the availability of many applications all contribute to the growth of this technology. Learning through technology has largely supplanted traditional education, owing to the availability of numerous multimedia learning resources (Lai \& Hwang, 2015:126).

The use of technology in education has the potential to improve students' learning process by making them more active, interesting, motivating, simulating, and meaningful (Singhal et al., 2012:1). One of the teaching materials that take advantage of technological developments is an interactive e-book. Huda et al., (2015:532) explained an interactive e-book is an e-book that contains animations, practicum videos containing material to be developed, practice questions and evaluations that students can directly complete and are accompanied by discussions. It also contains buttons that allow students to interact with the book by clicking on them. Najihah \& Sanjaya (2014:101) argues that an interactive e-book is a book that is available in a digital version that incorporates a combination of text, images, sound, and video that is accessible via computer or other media. Seso et al., (2018:178) argues that it is easier to integrate text, images, and videos into electronic teaching materials. Based on the above, it is required to build educational materials using technology, such as interactive e-books, that can be utilized to help students improve their problem-solving abilities when it comes to the circumference and area of plane figures.

\section{LITERATURE REVIEW}

Depdiknas (2007:148) Explaining teaching materials are a collection of materials that are organized in a systematic manner, both written and unwritten, to create an environment/atmosphere conducive to learning. According to the classification of teaching materials according to Prastowo $(2015: 248)$ explained that interactive e-books are a type of interactive teaching materials. Gui (2019:1) explained that an interactive e-book is a type of electronic book that allows for reader interaction. Chang et al., (2016:174) moreover, an interactive e-book is an ebook that has an interactive component that enables students to study more effectively. Chang et al., (2018:4) explains the interactive functions of the e-book including instructions, dragging, clicking, audiovisuals, and games. Puspitasari \& Rakhmawati (2013:540) Additionally, it was suggested that interactive e-books be described as active e-books. This is a book that has been created using a variety of media (audio, video, text, or graphics) and is interactive. This interactive aspect is useful for regulating commands or the 
presentation's natural behavior, allowing it to convey commands to the user to do an activity. Research by Ebied \& Rahman (2015) shows that the experimental group that used interactive e-books outperformed the control group that used printed books. The interactive e-book can boost student motivation and academic achievement. This is because multimedia in e-books is easily accessible and can be opened using a tablet or mobile phone, making e-books more convenient to use at any time and from any location.

Batoon et al., (2018) claims that interactive e-books are a form of technology-based learning. The design of interactive e-books can assist students in developing a variety of learning abilities, including the capacity to utilize technology, read and write, as well as cognition and metacognition. Additionally, it adds value due to its high audio-visual content. Huang et al., (2012) stated to develop an interactive e-book learning system for elementary school students. The study is based on technological developments such as Computers and tablets with high-resolution displays that have evolved into individual digital gadgets. This results in more flexible and accessible interactive ebooks that are larger than printed books. Additionally, the visual appeal enhanced by multimedia enables the incorporation of supplementary learning materials. The findings indicate that interactive e-books are more popular than printed books. Ormanci \& Cepni (2020) mentioned that teachers use interactive e-books and provide benefits when teaching. This is because e-books are created in a progressive manner that adheres to the objectives, curriculum, and is organized systematically. Additionally, students reported that they enjoyed the interactive e-books and thought they were attractive.

\section{MATERIALS \& METHODS}

This method of research is Research and Development (R\&D). ADDIE was employed as the research design. ADDIE's design process is divided into five stages: analysis, design, development, implementation, and evaluation. The analysis stage is the first step, in which problems in schools are identified through interviews with teachers and students on student difficulties, teaching materials, student problem-solving abilities, and instructional materials. The design stage is a process of developing a product based on the analysis's findings, namely by determining the software and website required to produce an interactive e-book. Corel Draw X7, Microsoft Power Point, Kinemaster, Microsoft Word, Pdf, Flip Pdf Corporate, and Website 2 APK Builder Pro are the software used. Wordwall, google form and YouTube are the website used. Second, make the material into a word file. The development stage is when the product is created and tested. To begin, use Flip Pdf Corporate to create and complete an interactive e-book. Second, validating interactive e-books with material experts to determine their validity of content in terms of content and linguistics, as well as with media experts to determine their presentation, graphic, and interactive elements. After an expert validator certified the content as valid, the interactive e-book was tested on a limited scale in the fifth grade of SD 1 Pasuruhan Lor to determine its practicality and readability.

The implementation stage is related to activities using the product that has been developed. At this stage, a large-scale trial was done in Pasuruhan Lor grades IV SD 1 and 2 to assess the effectiveness and response of pupils to interactive e-books. The evaluation stage is where the developed product's quality is determined, as well as its suitability. Each stage of the ADDIE design is evaluated. Questionnaires, interviews, and tests are used to collect data. The data collection instruments used were questionnaire sheets for material and media experts to assess the validity of interactive e-book content, teacher and student practicality questionnaire sheets to ascertain teacher and student responses regarding the 
Rahma Setiyanigrum et.al. Development of interactive e-books on plane figures materials to improve problem solving ability of grade IV students.

practicality of interactive e-books, a close test to determine the readability of interactive e-books, a written test to determine students' problem solving abilities, and student response questionnaires to verify student responses.

\section{Statistical Analysis}

Content validity, readability, practicality, and student responses to interactive e-books using the following formula.

$$
\begin{gathered}
P=\frac{f}{N} \times 100 \% \\
\text { Source : Sudijono (2018) }
\end{gathered}
$$

$P$ denotes the percentage score, $\mathrm{f}$ is the actual score, and $\mathrm{N}$ denotes the highest possible score for the assessment items. The requirements for content validity are listed in Table 1. If an interactive e-book achieves a percentage of $\geq 69$ percent, it is deemed to be content valid.

Table 1. Content Validity Criteria

\begin{tabular}{|l|l|}
\hline Percentage & Criteria \\
\hline $85,00 \%-100,00 \%$ & Very valid \\
\hline $69,00 \%-84,00 \%$ & Valid \\
\hline $53,00 \%-68,00 \%$ & Quite Valid \\
\hline $37,00 \%-52,00 \%$ & Less Valid \\
\hline $20,00 \%-36,00 \%$ & Invalid \\
\hline \multicolumn{2}{|r}{ Source: Rohmad et al., (2013:3) }
\end{tabular}

Table 2 summarizes Rankin and Culhane's criteria for the readability of instructional materials. If interactive ebooks pass the reading test with a score of $\geq 41 \%$, they are accepted.

Table 2. Readability Criteria

\begin{tabular}{|l|l|}
\hline Percentage & Criteria \\
\hline$P>60 \%$ & Easy to understand \\
\hline $41 \%<P \geq 60 \%$ & According to students \\
\hline$P \leq 40 \%$ & Difficult for students \\
\hline \multicolumn{2}{|l|}{ Source : Kusjuriansah \& Yulianto (2019:122) }
\end{tabular}

The practical criteria for interactive e-books can be seen in Table 3. Interactive e-books are said to be practical when the test results were $\geq 69 \%$.

Table 3. Practical Criteria

\begin{tabular}{|l|l|}
\hline Percentage & Criteria \\
\hline $85,00 \%-100,00 \%$ & Very Practical \\
\hline $69,00 \%-84,00 \%$ & Practical \\
\hline $53,00 \%-68,00 \%$ & Less Practical \\
\hline $37,00 \%-52,00 \%$ & Not Practical \\
\hline $20,00 \%-36,00 \%$ & Very impractical \\
\hline \multicolumn{2}{|c|}{ Source: Rohmad et al., (2013:3) }
\end{tabular}

The effectiveness of the interactive e-book was determined using the classical completeness and $\mathrm{N}$-gain tests. The following formula can be used to determine the classical completeness test.

$$
\begin{gathered}
\text { Persentase Ketuntasan }=\frac{\mathrm{t}}{\mathrm{n}} \times 100 \% \\
\text { Source }:(\text { Lintang \& Wardani, 2017) }
\end{gathered}
$$

$\mathrm{t}$ is the number of students who successfully complete the KKM, whereas n denotes the total number of students. The ability of students to solve problems is deemed to be classically complete when at least $75 \%$ of students reach the KKM.

The N-gain test can be calculated by the following formula.

$$
N-\text { Gain }=\frac{\text { Skor Postest }- \text { Skor Pretest }}{\text { Skor Maksimum }- \text { Skor Postest }}
$$

The data was converted to the $\mathrm{N}$ Gain value criteria based on the findings of the data analysis from the student's problemsolving abilities test. Table 4 details the criteria for determining the $\mathrm{N}$-gain value. If the normalized gain is classified as moderate or $0.30 \leq(\mathrm{g}) \quad 0.70$, students' problem-solving abilities are reported to improve (Lintang \& Wardani, 2017).

Table 4. Criteria for N-Gain value

\begin{tabular}{|l|l|}
\hline$N$-gain Value & Criteria \\
\hline$N$-Gain $\geq 0,70$ & High \\
\hline $0,30<N$-gain $\geq 0,70$ & Moderate \\
\hline$N$-gain $\leq 0,30$ & Low \\
\hline \multicolumn{2}{|c|}{ Source: Lestari \& Yudhanegara $(2015: 235)}$.
\end{tabular}

\section{RESULT}

It will be described as follows, based on the study that has been conducted regarding the development of interactive ebooks on flat-shaped materials to help fourth-grade students improve their problem-solving abilities.

\section{Interactive E-book Content Validity}

The first purpose of this study was to establish the validity of the content of the interactive e-book based on the results of validation by material and media experts. Table 5 summarizes the results of an 
Rahma Setiyanigrum et.al. Development of interactive e-books on plane figures materials to improve problem solving ability of grade IV students.

interactive e-book validation by material expert validators on the content and linguistic feasibility aspects.

Table 5. Interactive E-Book Validation Results by Material Experts

\begin{tabular}{|l|l|l|l|}
\hline No & Assessment Aspect & Pecsentage & Criteria \\
\hline 1 & Content eligibility & $87,50 \%$ & Very Valid \\
\hline 2 & language & $85,00 \%$ & Very Valid \\
\hline
\end{tabular}

According to Table 5, the content feasibility aspect receives a score of $87.50 \%$ with very valid criteria. The linguistic aspect receives a score of $85.00 \%$ with very valid criteria.

The findings of the validation of interactive e-books by media expert validators in terms of presentation, graphic design, and interactivity are shown in Table 6.

Table 6. Interactive E-Book Validation Results by Media Experts

\begin{tabular}{|l|l|l|l|}
\hline No & Assessment Aspect & Percentage & Criteria \\
\hline 1 & Presentation & $97,14 \%$ & Very Valid \\
\hline 2 & Graphics & $95,56 \%$ & Very Valid \\
\hline 3 & Interactive & $95,71 \%$ & Very Valid \\
\hline
\end{tabular}

According to Table 6, the presentation component receives a score of $97.14 \%$ using very valid criteria. The graphic aspect receives a percentage of $95.56 \%$ using very valid criteria. The interactive aspect receives a score of $95.71 \%$ using very valid criteria. Table 7 summarizes the validation findings of material experts and media experts for the development of interactive e-books.

Table 7. Recapitulation of the validation results of material experts and media experts.

\begin{tabular}{|l|l|l|l|}
\hline No & Assessment & Percentage & Criteria \\
\hline 1 & Material Expert & $86,67 \%$ & Very Valid \\
\hline 2 & Media Expert & $96,49 \%$ & Very Valid \\
\hline 3 & Average & $91,58 \%$ & Very Valid \\
\hline
\end{tabular}

According to Table. 7, the findings of interactive e-book validation by material experts a score of $86.67 \%$ with very valid criteria. The validation of the interactive ebook by media experts a score of $96.49 \%$ with very valid criteria. The average validation result from material and media experts is $91.58 \%$ with very valid criteria. The validation results indicate that the constructed interactive e-book is suitable for teaching mathematics about the circumference and area of plane figures such as squares, rectangles, and triangles.

\section{Interactive E-Book Readability}

The second purpose of this study was to ascertain the readability of interactive e-books, which were evaluated using a close test in which the sixth word was omitted. The close test was conducted on 10 fifth-grade students from SD 1 Pasuruhan Lor in a small-scale study. The close test's results are shown in Table 8 .

\begin{tabular}{|c|c|c|c|}
\hline $\begin{array}{l}\text { Scores } \\
\text { obtained by } \\
\text { students }\end{array}$ & $\begin{array}{l}\text { Maximum } \\
\text { Score }\end{array}$ & Result & Criteria \\
\hline 101 & 160 & $63,13 \%$ & Easy to understand \\
\hline
\end{tabular}

According to Table 8, the percentage of close test results was $63.13 \%$, indicating that the interactive e-book developed in accordance with the criteria is easy to understand.

\section{The Practicality of Interactive E-Books}

The third research objective of this study was to ascertain the practicality of interactive e-books from both the teacher and student perspectives. The questionnaire assesses three aspects of practicality: ease of use, attractiveness, and efficiency. The following are the results of the practicality analysis based on a questionnaire administered to the fifth-grade teacher and 10 fifth grade pupils of SD 1 Pasuruhan Lor during a small-scale trial. Table 9 contains the results of the teacher's practicality questionnaire.

Table 9. Teacher Practicality Questionnaire Results

\begin{tabular}{|l|l|l|l|l|}
\hline Aspect & Score by Teachers & Maximum Score & Result & Criteria \\
\hline Ease of Use & 22 & 25 & $88.00 \%$ & Very Practical \\
\hline Attractiveness & 28 & 30 & $93.33 \%$ & Very Practical \\
\hline Efficiency & 26 & 30 & $86.67 \%$ & Very Practical \\
\hline Overall Score Percentage & 76 & 85 & $89.41 \%$ & Very Practical \\
\hline
\end{tabular}


According to Table 9, the teacher's practicality questionnaire on interactive ebooks received an overall score of $88.00 \%$ with very practical criteria. With very practical criteria, the attractiveness aspect receives a score of $93.33 \%$. The efficiency factor receives a score of $86.67 \%$. Overall, the teacher practicality questionnaire scores $89.41 \%$ with very practical criteria, indicating that the generated interactive ebooks are practical to use.

Table 10 contains the results of the student practicality questionnaire.

Table 10. Student Practicality Questionnaire Results

\begin{tabular}{|l|l|l|l|l|}
\hline Aspect & Score by Teachers & Maximum Score & Result & Criteria \\
\hline Ease of Use & 238 & 250 & $95.20 \%$ & Very Practical \\
\hline Attractiveness & 230 & 250 & $92.00 \%$ & Very Practical \\
\hline Efficiency & 185 & 200 & $92.50 \%$ & Very Practical \\
\hline Overall Score Percentage & 653 & 700 & $93.29 \%$ & Very Practical \\
\hline
\end{tabular}

Based on Table 10, the results of the students' practicality questionnaire on interactive e-books on the ease of use aspect got a percentage of $95.20 \%$ with very practical criteria. The attractiveness aspect gets a percentage of $92.00 \%$ with very practical criteria. The efficiency aspect gets a percentage of $92.50 \%$ with very practical criteria. Overall the results of the practicality questionnaire students get a percentage of $93.29 \%$ with very practical criteria, meaning that the interactive e-books developed are practical to use.

\section{Effectiveness of Interactive E-Books}

Table 11. Classical Completeness Test Results Classical Mastery Test Results

\begin{tabular}{|l|l|}
\hline Average student final grade & 69,08 \\
\hline The highest score & 90,00 \\
\hline Lowest value & 27,50 \\
\hline Number of students who completed & 29 \\
\hline Number of students incomplete & 9 \\
\hline Total number of students & 38 \\
\hline Classical completeness & $76,32 \%$ \\
\hline
\end{tabular}

The study's fourth research objective was to determine the effectiveness of interactive e-books. An interactive e-book that was verified and tested on a small scale trials before being tested on a large-scale trials with 38 students, 6 fourth grade students from SD 1 Pasuruhan Lor and 32 grade IV students from SD 2 Pasuruhan Lor. Large-scale trials were conducted to determine the effectiveness of the interactive e-book material in improving students' circumference and area of flat forms such as squares, rectangles, and triangles. The effectiveness of this interactive e-book includes classical completeness test and n-gain. The results of the classical completeness test are shown in Figure 11.

Based on Table 11, 29 students out of 38 students have completed learning, resulting in a percentage value of $76.32 \%$ for classical completeness. Table 12 contains the findings of the n-gain test.

Table 12. N-gain test results
\begin{tabular}{|l|l|l|l|l|}
\hline Pre-test & Post-test & Maximum Score & N-gain & Criteria \\
\hline 274 & 1020 & 1520 & 1.49 & High \\
\hline
\end{tabular}

Based on Table 12, the $\mathrm{N}$-gain value is 1.49 with very high criteria.

\section{Student Responses to Interactive E-Books}

The fifth objective was to determine student responses to interactive e-books is 6 fourth grade students from SD 1 Pasuruhan Lor and 32 grade IV students from SD 1 Pasuruhan Lor replied to the student response questionnaires. Table 13 contains the results of the student response questionnaire. Table 13. Results of Student Response Questionnaires

\begin{tabular}{|l|l|l|l|}
\hline Student's Score & Maximum Score & Result & Criteria \\
\hline 4917 & 5320 & $92,42 \%$ & Very good \\
\hline
\end{tabular}

Based on Table 13, the student response questionnaire score was $92.42 \%$, so the interactive e-book developed got a very good response by students.

\section{DISCUSSION}

\section{Interactive E-Book Content Validity}

Expert validators' findings on the feasibility of content obtained a percentage 
of $87.50 \%$ using very valid criteria. This means that the material in the interactive ebook has been prepared in accordance with $\mathrm{KD}$ (basic competencies) and indicators. The presented material encompasses the entirety of the specified KD (basic competencies) and Indicators. The material preparation process began with the introduction of concepts, definitions in each sub-chapter, examples, and practice questions, as well as interactive e-book material providing indicators of problemsolving abilities. Examples and practice questions in the interactive e-book are contextual and in accordance with the material $\mathrm{c}$. The material contained in the interactive e-book is trusted, as evidenced by the presence of clear sources in the bibliography. The interactive e-book's material enables students to completely study the text, to develop their own knowledge, and to practice problem solving abilities. Examples and practice questions are complemented with images, videos, and animations that assist students in resolving material-related challenges. The feasibility of the content is the most critical factor to consider, as it is directly related to the material discussed in the book (Wahyuningsih et al., 2018:27).

The linguistic aspect obtained a percentage of $85.00 \%$ with very valid criteria. Based on the results of these percentages, it shows that the language in the interactive e-book is in accordance with the development of students and is communicative. Wahyuningsih et al., (2018) emphasizes that the language used in a book must be communicative for the message or information to be transmitted to the reader effectively. The use of dialogic and interactive language, as well as straightforwardness, coherence, and a coherent method of thinking, are all beneficial. Additionally, the phrase symbols or symbols is used consistently and correctly in interactive e-books. The language adheres to the requirements of proper Indonesian. Purnanto \& Mustadi (2016:110) explained that with good grammar and standard spelling will provide the right foundation for students.

With very valid criteria, the presentation aspect received a percentage of $97.14 \%$. This indicates that the structure of interactive e-books is consistent with the structure of teaching materials. The content is given consistently and logically, progressing from easy to difficult, concrete to abstract, and simple to complex. The information is presented in such a way that students are the focus of learning and is structured in an interactive and participatory manner that encourages students to take an active role in acquiring competence. The accompanying presentations, which include forewords, book descriptions, benefits of usage, a table of contents, a list of illustrations, material charts, summaries, a bibliography, a glossary, and navigation buttons, are all well-organized. The visual, audio, video, and animation quality of an interactive e-book that explains the topic is obvious.

With extremely valid criteria, aspects of graphics obtained a percentage of $95.56 \%$. This indicates that the title of the interactive e-book is quite appealing; the cover design incorporates cartoon images and accurately defines the topic that students will study. The typeface chosen for the cover is attractive, legible, and clear. The information of the interactive e-book is organized in a straightforward, beautiful, and consistent manner. The color composition of the interactive e-book content is balanced. Hersandi et al., (2017:59) the graphic aspect must be examined since it influenced the physical appearance of teaching materials, which can increase students' motivation and attractiveness to read and understand them.

With very valid criteria, the interactive feature received a percentage of $95.71 \%$. This means that interactive ebooks already include questions inviting readers to engage, as well as instruction, dragging, clicking, audio visual, and gaming functions. According to the results of expert validation on the feasibility of content, 
linguistics, presentation, graphic design, and interactivity, interactive e-books are very varlid for use in learning mathematics. The material for circumference and area of plane figures includes squares, rectangles, and triangles.

\section{Interactive E-Book Readability}

According to the research findings, interactive e-books have a readability score of $63.13 \%$ when measured against the criteria of being easy to understand. This indicates that the material is presented in a manner consistent with good and correct Indonesian grammar, with a simple sentence structure, and without the use of foreign or difficult-to-understand vocabulary. The use of simple language and simple sentences will aid in the transmission of the message, ensuring that it is easily comprehended by students (Nugraha et al., 2013:64). The level of readability is also largely determined by the availability of images or illustrations that accompany the paragraph (Dewi, 2013:11). Another factor affecting readability, as determined by the findings of the close test study, is the use of synonyms. The close test revealed that while the student's responses did not match the keywords, the term chosen by the student was a synonym for the word that was eliminated. The word "terdapat" is erased, and the student's close test response is replaced with another response, particularly the word "ada."

\section{The Practicality of Interactive E-Books}

According to the results of the practicality questionnaire analysis, interactive e-books were used practically in mathematics education. This is because interactive e-books facilitate and expedite the learning process, may be used effectively to create a pleasant learning environment, and motivate students to learn, and can be used or utilized effectively in the mathematical learning process. This is consistent with the findings of a study conducted by Suprapto et al., (2019) that the level of practicality associated with developing learning media through the use of visual-based interactive online e-books and series content is very practical. Teachers can employ practical media and teaching materials to assist students in obtaining their competencies (Apriliani et al., 2020:219).

\section{Effectiveness of Interactive E-Books}

Based on students' classical completeness scores of $76.32 \%$. $>75 \%$, the results of their problem solving ability tests are considered to be classically complete. The n-gain test of students' problem-solving abilities yielded a score of 1.49 with high criteria. It may be concluded that the interactive e-book product developed is effective for teaching fourth grade students about the perimeter and area of flat objects and for improving their problem solving abilities. This is consistent with the findings of a study conducted by Mursalin (2019:32) stated learning through interactive e-books significantly improves mathematical critical thinking skills and is significantly better than learning through conventional textbooks, making it easier for students to understand the material independently, particularly when learning mathematics.

\section{Student Responses to Interactive E-Books}

Student responses to learning using an interactive e-book product developed achieved a percentage of $92.42 \%$ utilizing very good criteria. This is because the interactive e-book material on the circumference and area of flat forms such as squares, rectangles, and triangles is arranged in an engaging manner that captures students' interest. Batlolona (2016:4) Additionally, it has been suggested that interactive teaching materials provide beauty and attractiveness; the presence of interactivity in a teaching material is a means of ensuring that students are not bored while participating in learning; and the greatest effect is expected to motivate students to learn and make receiving learning materials easier. 
Rahma Setiyanigrum et.al. Development of interactive e-books on plane figures materials to improve problem solving ability of grade IV students.

\section{CONCLUSION}

An interactive e-book is a type of electronic book that integrates text, still images, animation, audio, and video learning. The results showed that the content validity was $86.67 \%$ with very good criteria for material expert validators and 96.49\% with very valid criteria for media expert validators. According to the close test, the readability of the interactive e-book is $63.13 \%$ with easy to understand criteria. The practicality of the interactive e-book is reported to be very practical, as seen by the teacher practicality questionnaire's result of $89.41 \%$ and the student practicality questionnaire's result of $93.23 \%$. The effectiveness of the interactive e-book is determined by the percentage value of classical completeness being $76.32 \%>$ $75 \%$, which indicates that the results of the student's problem solving ability test are classically complete, and the $\mathrm{N}$-gain value being 1.49 with very high criteria. The student response questionnaire for the interactive e-book was rated as very good, with a percentage of $92.42 \%$. Based on the results of the research, it can be stated that the development of an interactive e-book of plane figures materials to improve the problem-solving abilities $s$ of fourth grade students is valid, readable, practical, effective, and gets a good response from students.

\section{Acknowledgement: None}

\section{Conflict of Interest: None}

\section{Source of Funding: None}

\section{REFERENCES}

1. Apriliani, L. R., Irham, M., \& Darojat, L. (2020). Pengembangan Media dan Bahan Ajar Interaktif Scan Berbasis Geogebra. Kreano, Jurnal Matematika KreatifInovatif, $\quad 11(2), \quad 213-222$. https://journal.unnes.ac.id/nju/index.php/kre ano/article/view/26909

2. Batlolona, J. R. (2016). Hasil Belajar Kognitif dan Respon Siswa dalam Pembelajaran Fisika Pada Konsep Listrik
Dinamis dengan Menerapkan Media Interaktif. Jurnal Pendidikan IPA Pascasarjana UM, 1(1-8).

3. Batoon, M. V. P., Morales, L. D. G., \& Figuero, J. A. Y. (2018). Instructional Design To Measure The Efficacy Of Interactive E-Books In A High School Setting. Turkish Online Journal of Distance Education, 19(2), 47-60.

4. Chang, S. C., Wang, S. Y., \& Hwang, G. J. (2016). A repertory grid-based interactive ebook approach to supporting in-field mobile learning activities in an ecology course. International Journal of Mobile Learning and Organisation, 10(3), 171-186. https://doi.org/10.1504/IJMLO.2016.077868

5. Chang, W.-H., Huang, T.-H., \& Liu, Y.-C. (2018). Influence of an Interactive e-Book on the Reading Comprehension of Different Ethnic Groups Using Indigenous Culture as Content. International Journal of HumanComputer Interaction, OO(00), 1-10. https://doi.org/10.1080/10447318.2018.154 3079

6. Depdiknas. (2007). Pedoman Memilih dan Menyusun Bahan Ajar. Departemen Pendidikan Nasional.

7. Dewi, P. P. T. K. (2013). Tingkat Keterbacaan Buku Teks Bahasa Indonesia untuk Siswa Kelas XI IPA 1 SMAN 1 Blahbatuh melalui Uji Tes Rumpang. Jurnal Pendiikan Bahasa Dan Sastra Undiskha, 1(4), 1-12.

8. Ebied, M. M. A., \& Rahman, S. A. A. (2015). The effect of interactive e-book on students ' achievement at Najran University in computer in education course. Journal of Education and Practice, 6(19), 71-83.

9. Fauzi, I., \& Arisetyawan, A. (2020). Analisis Kesulitan Belajar Siswa pada Materi Geometri Di Sekolah Dasar. Kreano, Jurnal Matematika Kreatif-Inovatif, 11(1), 27-35. https://doi.org/10.15294/kreano.v11i1.2072 6

10. Gui, X. (2019). The Design and Creation of an Interactive E-Book: "book of Answer." Journal of Physics: Conference Series, 1187(5). $\quad$ https://doi.org/10.1088/17426596/1187/5/052018

11. Hersandi, M., Mahardika, I. K., \& Nuriman. (2017). Pengembangan Bahan Ajar Lembar Kerja Siswa (LKS) dalam Bentuk Brosur Untuk Pembelajaran IPA di SMP ditinjau dari Aspek Kegrafikaannya. Jurnal 
Rahma Setiyanigrum et.al. Development of interactive e-books on plane figures materials to improve problem solving ability of grade IV students.

Pembelajaran Dan Pendidikan Sains, 2(1), 57-64. http//jurnal.unej.ac.id

12. Huang, Y., Liang, T., Su, Y., \& Chen, N. (2012). e-book learning system for elementary school students. Educational Technology Research and Development, 60(4), 703-722. https://doi.org/10.1007/s11423-012-9237-6

13. Huda, T. A., Fadiawati, N., \& Tania, L. (2015). Pengembangan E-book Interaktif pada Matri Termokimia Berbasis Representasi Kimia. Jurnal Pendidikan Dan Pembelajaran Kimia, 4(2), 530-542.

14. Isrok'atun, \& Rosmala, A. (2018). ModelModel Pembelajaran Matematika. Bumi Aksara.

15. Kemendikbud. (2017). Model Silabus Mata Pelajaran Matematika Sekolah Dasar/Madrasah Ibtidaiyah (SD/MIO. Kemendikbud.

16. Kusjuriansah, K., \& Yulianto, A. (2019). Pengembangan Bahan Ajar Fisika Berbasis I-SETS Terkomplementasi Karakter Pada Materi Hukum Gravitasi Newton. Unnes Physics Education Journal, 8(2), 120-132. http://journal.unnes.ac.id/sju/index.php/upej

17. Lai, C. L., \& Hwang, G. J. (2015). High school teachers' perspectives on applying different mobile learning strategies to science courses: The national mobile learning program in Taiwan. International Journal of Mobile Learning and Organisation, 9(2), 124-145. https://doi.org/10.1504/IJMLO.2015.070704

18. Laurens, T., Batlolona, F. A., Batlolona, J. R., \& Leasa, M. (2018). How Does Realistic Mathematics Education (RME) Improve Students' Mathematics Cognitive Achievement? Eurasia Journal of Mathematics, Science and Technology Education, 14(2), 569-578. https://doi.org/10.12973/ejmste/76959

19. Lestari, K. E., \& Yudhanegara, M. R. (2015). Penelitian Pendidikan Matematika. PT Refika Aditama.

20. Lintang, A. C., \& Wardani, S. (2017). PBL dengan APM untuk Meningkatkan Kemampuan Pemecahan Masalah dan Sikap Percaya Diri. Journal of Primary Education, 6(1), 27-34.

21. Loc, N. P., \& Phuong, N. T. (2015). Opinions on Mathematics Word Problems in Primary Schools: A Survey of Teachers and Students in the City "Bac Lieu"-
Vietnam. European Academic Research, II(11), 14561-14564.

22. Mursalin. (2019). The Critical Thinking Abilities in Learning Using Elementary Algebra E-Books: A Case Study at Public Universities in Indonesia. Malikussaleh Journal of Mathematics Learning (MJML), 2(1), 29-33.

23. Najihah, S., \& Sanjaya, I. G. M. (2014). Pengembangan Model E-Book Interaktif Termodifikasi Majalah Pada Materi Struktur Atom. Unesa Journal of Chemical Education, 3(3), 100-104.

24. Nugraha, E. A., Yulianti, D., \& Khanafiyah, S. (2013). Pembuatan Bahan Ajar Komik Sains Inkuiri Materi Benda untuk Mengembangkan Karakter Siswa Kelas IV SD. Unnes Physics Education Journal, 2(1), 60-68.

25. Ormanc1, Ü., \& Çepni, S. (2020). Views on interactive e-book use in science education of teachers and students who perform ebook applications. Turkish Online Journal of Qualitative Inquiry, 11(2), 247-279. https://doi.org/10.17569/tojqi.569211

26. Prastowo, A. (2015). Panduan Kreatif Membuat Bahan Ajar Inovatif (Cetakan VI). Diva Press.

27. Purnanto, A. W., \& Mustadi, A. (2016). Analisi Kelayakan Bahasa dalam Buku Teks Tema 1 Kelas I Sekolah Dasar Kurikulum 2013. Profesi Pendidikan Dasar, 3(2), 102111.

28. Puspitasari, A., \& Rakhmawati, L. (2013). Interactive E-book Development on Digital Electronics Courses. Jurnal Pendidikan Teknik Elektro, 2(2), 537-543.

29. Rohmad, A., Suhandini, P., \& Sriyanto. (2013). Pengembangan Lembar Kerja Siswa (LKS) Berbasis Eksplorasi, Elaborasi, dan Konfirmasi (EEK) serta Kebencanaan sebagai Bahan Ajar Mata Pelajaran Geografi SMA/MA di Kabupaten Rembang. Edu Geography, 1(2), 1-5. http://journal.unnes.ac.id/sju/index.php/edug eo

30. Seso, M. A., Laksana, D. N. L., \& Dua, K. (2018). Pengembangan Bahan Ajar Elektronik Bermuatan Multimedia Untuk Siswa Sekolah Dasar Kelas IV di Kabupaten Ngada. Journal of Education Technology, 2(4), 177-185.

31. Singhal, S., Bagga, S., Goyal, P., \& Saxena, V. (2012). Augmented Chemistry: Interactive Education System. International 
Rahma Setiyanigrum et.al. Development of interactive e-books on plane figures materials to improve problem solving ability of grade IV students.

Journal of Computer Applications, 49(15), 1-5. https://doi.org/10.5120/7700-1041

32. Sudijono, A. (2018). Pengantar Statistik Pendidikan. PT Raja Grafindo Persada.

33. Suprapto, E., Apriandi, D., \& Pamungkas, I. P. (2019). Pengembangan E-Book Interaktif Berbasis Animasi Bagi Siswa Sekolah Menengah Kejuruan. ANARGYA: Jurnal Ilmiah Pendidikan Matematika, 2(2), 124130.

http://jurnal.umk.ac.id/index.php/anargya

34. Wahyuningsih, L., Suhita, R., \& Wardani, E. (2018). Analisis Kelayakan Buku Teks Bahasa Jawa Kurikulum 2013 Tingkat Smp. Jurnal Sabdasastra, 2(2), 25-42.
35. Zuliana, E. (2015). Pengaruh Model Problem Based Learning Berbantuan Kartu Masalah Terhadap Kemampuan Pemecahan Masalah Matematika Siswa Sekolah Dasar. Refleksi Edukatika: Jurnal Ilmiah Kependidikan, https://doi.org/10.24176/re.v5i1.440

How to cite this article: Rahma Setiyanigrum, Endang Susilaningsih, Nas Haryati Setyaningsih. Development of interactive ebooks on plane figures materials to improve problem solving ability of grade IV students. International Journal of Research and Review. 2022; 9(2): 297-307. DOI: https://doi.org/10. 52403/ijrr.20220240 